\title{
Effect of Different Zeolite Supported Bifunctional Catalysts for Hydrodeoxygenation of Waste Wood Bio-oil ${ }^{1}$
}

\author{
Shinyoung $\mathrm{Oh}^{2} \cdot$ Sye-Hee $\mathrm{Ahn}^{3} \cdot$ Joon Weon Choi $\mathbb{D}^{2,4, \dagger}$
}

\begin{abstract}
Effects of various types of zeolite on the catalytic performance of hydrodeoxygenation (HDO) of bio-oil obtained from waste larch wood pyrolysis were investigated herein. Bifunctional catalysts were prepared via wet impregnation. The catalysts were characterized through XRD, BET, and SEM. Experimental results demonstrated that HDO enhanced the fuel properties of waste wood bio-oil, such as higher heating values (HHV) (20.4-28.3 MJ/kg) than bio-oil (13.7 $\mathrm{MJ} / \mathrm{kg}$ ). Water content (from 19.3 in bio-oil to 3.1-16.6 wt\% in heavy oils), the total acid number (from 150 in bio-oil to $28-77 \mathrm{mg} \mathrm{KOH/g}$ oil in heavy oils), and viscosity (from 103 in bio-oil to $40-69 \mathrm{~mm}^{2} / \mathrm{s}$ in heavy oils) also improved post HDO. In our experiments, depending on the zeolite support, NiFe/HBeta exhibited a high Si/Al ratio of 38 with a high specific surface area $\left(545.1 \mathrm{~m}^{2} / \mathrm{g}\right)$, and, based on the yield of heavy oil (18.3-18.9 wt\%) and HHV (22.4-25.2 $\mathrm{MJ} / \mathrm{kg}$ ), its performance was not significantly affected by temperature and solvent concentration variations. In contrast, $\mathrm{NiFe} /$ zeolite $\mathrm{Y}$, which had a low Si/Al ratio of 5.2, exhibited the highest improved quality for heavy oil at high temperature, with an $\mathrm{HHV}$ of $28.3 \mathrm{MJ} / \mathrm{kg}$ at $350{ }^{\circ} \mathrm{C}$ with $25 \mathrm{wt} \%$ of solvent.
\end{abstract}

Keywords: bio-oil, hydrodeoxygenation, waste wood, bifunctional catalyst, zeolite

\section{INTRODUCTION}

For the recent decades processes of biomass conversion into renewable fuels has been attracting much attention due to decreasing of crude-oil reserves, enhanced demand for fuels worldwide and increased climate concerns about the use of fossil-based energy carriers (Zhang et al., 2015; Kim 2016; Prajitno et al., 2016; Chiaramonti et al., 2017; Zhang et al., 2018).
In contrast to fossil fuel reserves, biomass is indicated as an abundant, sustainable and carbon-neutral renewable energy resource for the production of biofuels and valuable chemicals.

In particular, Korea is the world's 10th largest emitter of carbon dioxide and should be reducing greenhouse gas emissions from 2013. According to the Korea Wood recycling association, the production of waste wood in Korea is about 5 million ton, and the waste from

\footnotetext{
${ }^{1}$ Date Received February 19, 2019, Date Accepted May 13, 2019

2 Institute of Green-Bio Science and Technology, Pyeongchang, Gangwon-do 25354, Seoul National University, Republic of Korea

${ }^{3}$ Department of Forest Resources, Daegu University, Gyeongsan 52828, Republic of Korea

${ }^{4}$ Graduate School of International Agricultural Technology, Pyeongchang, Gangwon-do 25354, Seoul National University, Republic of Korea

† Corresponding author: Joon Weon Choi (e-mail: cjw@snu.ac.kr, ORCID: 0000-0002-9454-0475)
} 
Effect of Different Zeolite Supported Bifunctional Catalysts for Hydrodeoxygenation of Waste Wood Bio-oil

afforestation is the highest amount, 48\% in 2005. The amount of waste wood decreased to 2 million ton in 2016, and 66\% those waste wood is recycled, as charcoal or combustion in combined heat and power (CHP) system. The Korea ministry of environment established the law related to waste-to-energy and biomass-toenergy in 2009, and the Renewable Energy Portfolio Standard (RPS) was enforced from 2012.

Larch (Larix kaempferi) forests are the dominant forest type through northeastern Asia to central Siberia. The net ecosystem production (NEP) of a larch forest has been routinely measured by the eddy covariance method at the Tomakomai flux site since the autumn of 2000 (Hirano et al., 2003). In Hokkaido, Japan, larch plantations (470,000 ha) account for about one third of all forests, because of their high productivity (Liang et al., 2004).

Fast pyrolysis technology is commonly used for the biomass conversion into liquid products, referred to as bio-oil. The bio-oil composition depends on the type of feedstock (biomass) and the pyrolysis conditions (Bridgwater, 2012). However, the high content of oxygen usually leads to disadvantageous fuel features, like high viscosity, thermal and storage instability, corrosiveness, poor heating value and immiscibility (Wen et al., 2014; Long et al., 2015; Moon et al., 2016; Lee et al., 2016; Prajitno et al., 2016; Zhang et al., 2018) and makes it complicated for direct use (Lu et al., 2009). The key reaction of this process is the hydrogenolysis of $\mathrm{C}-\mathrm{O}$ bonds (hydrodeoxygenation) of oxygen-containing compounds with the formation of water (Choudhary 2011; Mortensen et al., 2011).

Early work indicated that conventional hydrodesulphurization (HDS)/hydrodenitrogenation (HDN) catalysts exhibit promising activity in hydrodeoxygenation (HDO) of phenolic compounds such as phenol, anisole, and guaiacol (Bredenberg et al., 1982; Laurent et al., 1994b; Centeno et al., 1995; Ferrari et al., 2001; Buiet al., 2011a). However, these metal-sulfide catalysts suffer from deactivation in the presence of high water content and the continuous addition of sulfur is required in the reactant stream to maintain the catalysts in the sulfide form. This last factor in particular can cause serious problems for the downstream processes (Laurent 1994a; Ferrari et al., 2001; Zakzeski et al., 2010). Alternative hydrotreating catalysts have been sought for bio-oil upgrading (Elliott 2008; Wildschut et al., 2009; Zakzeski et al., 2010; González-Borja 2011; Nimmanwudipong et al., 2011b; Zhao et al., 2011; Zhu et al., 2011). Recently, Gates' group compared $\mathrm{Pt} / \mathrm{Al}_{2} \mathrm{O}_{3}$ and $\mathrm{Pt} / \mathrm{HY}$ catalysts in the HDO of anisole and guaiacol. Their results showed that the transalkylation activity of the catalyst was significantly affected by the type of acidic site (Nimmanwudipong et al., 2011a; Nimmanwudipong et al., 2012). A later study by Zhu et al. further confirmed the effect of acidic sites on the transalkylation activity in the HDO of anisole (Zhu et al., 2011). A very recent report indicates that $\mathrm{Fe} / \mathrm{SiO}_{2}$ shows a higher hydrodeoxygenation activity without saturation of aromatic ring in the guaiacol conversion (Olcese et al., 2012). While the transalkylationactivity of the acidic catalyst offers a way to preserve the carbon from being lost as a gas product, the presence of acidic sites interacts strongly with the phenolic compounds, resulting in rapid catalyst deactivation by coking (Centeno et al., 1995; Huber et al., 2006) Moreover, bifunctional catalysts comprised by active metal and solid acid exhibits excellent activity for HDO reaction. Support material is also thekey factor determining the catalytic performance as well as active metal. ã- $\mathrm{Al}_{2} \mathrm{O}_{3}$, which was widely used for HDO due to cheap cost, excellent texture and suitable acidity, showed excellent HDO activity in the HDO of phenolic compounds (Bui et al., 2011b; Zhang et al., 2013), occurred high amount of coke formation as well as boehmite resulting decrease the catalytic activity. Therefore, finding the suitable catalysts to overcome those drawbacks is conducted in numerous studies. For 
example, Ni/HZSM-5, Pt/HZSM-5, Ru/HBeta and $\mathrm{Pt} / \mathrm{HBeta}$ could effectively transformed guaiacol into hydrocarbons (Zhu et al., 2011; Zhao 2012; Ohta et al., 2015; Yao et al., 2015; Zhanget al., 2018).

Here, we describe the preparation and reactivity for a series of bifunctional catalysts for the HDO of waste wood bio-oil. Especially, effect of support zeolite with NiFe bimetallic catalysts on the heavy oil products after HDO process will be investigated by analyzing catalysts and product features.

\section{MATERIALS and METHODS}

\subsection{Preparation and characterization of $\mathrm{NiFe}$ bimetallic catalysts}

\subsubsection{Preparation of the catalysts}

Catalytically active transition metal sites ( $\mathrm{Ni}$ and $\mathrm{Fe}$ ) were added by means of a wet impregnation method (Yakovlev et al., 2009; Ardiyanti et al., 2012). Equal amounts of nitrate-form transition metal ( $\mathrm{Ni}$ and $\mathrm{Fe}$ ) solution and three zeolite supportswere stirred for 1 h. After the mixture was homogenized, it was dried overnight at $80{ }^{\circ} \mathrm{C}$ and calcined in air at $550{ }^{\circ} \mathrm{C}$ for $3 \mathrm{~h}$ to obtain NiFe/HBeta, NiFe/ZSM- 5 and NiFe/Zeolite Y. The catalysts were reduced at $500{ }^{\circ} \mathrm{C}$ for $3 \mathrm{~h}$ under an $\mathrm{H}_{2}$ atmosphere before use. Two commercial catalysts $\left(\mathrm{CoMo} / \mathrm{Al}_{2} \mathrm{O}_{3}\right.$ and $\mathrm{NiMo} / \mathrm{Al}_{2} \mathrm{O}_{3}$ ) were also performed HDO reaction to compare the activity.

\subsubsection{BET specific surface area}

The specific surface areas of the support and catalysts were measured by means of a Brunauer-Emmett-Teller (BET) method, and the pore distributions and cumulative pore volumes were calculated by means of the Barret-Joyner-Halenda (BJH) method, based upon the desorption branches of the $\mathrm{N}_{2}$ isotherms measured at $77 \mathrm{~K}$. Samples were degassed at $523 \mathrm{~K}$ for $4 \mathrm{~h}$ before these tests.

\subsubsection{Crystallinity of transition metal active sites}

X-ray powder diffraction patterns (XRD) were acquired using a Bruker D8 Advance with a $\mathrm{Cu} \mathrm{K \alpha}$ radiation source ( $\lambda=1.5418 \AA$ ), operated at $40 \mathrm{kV}$ and $40 \mathrm{~mA}$ with the scan speed of $0.5 \%$ min over the range $10-70{ }^{\circ}(2 \theta)$.

\subsubsection{Degree of metal dispersion on three zeolite supports by SEM}

The morphology of each of the catalysts was investigated by means of FE-SEM (field-emission scanning electron microscopy, AUGIRA).

\subsection{Batch type hydrodeoxygenation of bio-oil from Larch}

Bio-oil obtained from fast pyrolysis of waste wood was offered from Yonsei University. A stainless steel reactor equipped with a thermocouple, a pressure sensor, and a system for controlling the temperature and pressure was used as the test chamber. $4 \mathrm{wt} \%$ of the reduced catalysts were added to a mixture of bio-oil and ethanol and then placed into the sealed reactor and flushed with $\mathrm{N}_{2}$. The reactor was then pressurized to $3 \mathrm{MPa}_{2}$, and the temperature was increased to the reaction temperature (300,350, or 400 ${ }^{\circ} \mathrm{C}$ ) (Laurent 1994b; Ferrari et al., 2001). The ethanol concentration varied 25,10 , and $5 \mathrm{wt} \%$ in the mixture. Three zeolite supportedcatalyst (NiFe/HBeta, NiFe/ ZSM-5 and NiFe/ Zeolite $\mathrm{Y}$ ) and two commercial catalysts $\left(\mathrm{CoMo} / \mathrm{Al}_{2} \mathrm{O}_{3}\right.$ and $\left.\mathrm{NiMo} / \mathrm{Al}_{2} \mathrm{O}_{3}\right)$ were performed HDO reaction to test the activity. After the reaction, three phases of four products were obtained: liquid (immiscible light oil and lower heavy oil), char, and gas. The upper solvent-based water-rich light oil and lower organic heavy oil were recovered after the reaction and separated using a separatory funnel. The yields of char, light oil and heavy oil were calculated according to the following equations. 
Effect of Different Zeolite Supported Bifunctional Catalysts for Hydrodeoxygenation of Waste Wood Bio-oil

Yield of char (\%)

$=[$ Solid $(\mathrm{g})-$ Catalyst $(\mathrm{g})] /[$ Bio-oil $(\mathrm{g})$

+ Ethanol $(\mathrm{g})] \times 100$

Yield of light oil (\%)

$=[$ Light oil (g) $] /[$ Bio-oil (g) + Ethanol (g) $]$

$\times 100$

Yield of heavy oil (\%)

$=[$ Heavy oil (g) $] /[$ Bio-oil $(g)+$ Ethanol

(g) $] \times 100$

Yield of gas (\%)

$=100-$ [Yield of light oil + Yield of heavy oil + Yield of char]

\subsection{Measuring fuel quality of heavy oil obtained from HDO}

\subsubsection{Physicochemical properties}

To measure the water content and acidity (total acid number, TAN) of the bio-oil and heavy oils, Karl Fischer titration and ASTM D664 TAN testing were performed. Each sample was analyzed three times; values reported in tables herein represent the averages of the triplicate analyses. Viscosities were determined at $20{ }^{\circ} \mathrm{C}$ using a VIBRO viscometer (AND, Japan). The higher heating value (HHV) was calculated according to the following equation (Friedl et al., 2005):

$$
\begin{aligned}
\mathrm{HHV} /(\mathrm{J} / \mathrm{kg})= & 3.55 \mathrm{x}[\mathrm{C}]^{2}-232 \mathrm{x}[\mathrm{C}]-2230 \mathrm{x}[\mathrm{H}] \\
& +51.2 \mathrm{x}[\mathrm{H}] \mathrm{x}[\mathrm{C}]+131 \mathrm{x}[\mathrm{N}]+20,600
\end{aligned}
$$

where $[\mathrm{C}],[\mathrm{H}]$, and $[\mathrm{N}]$ are the mass\% of carbon, hydrogen, and nitrogen on dry basis, respectively. The results were corrected for the water content of the oil.

Atomic $\mathrm{O} / \mathrm{C}$ and $\mathrm{H} / \mathrm{C}$ were calculated to compare the hydrogenation and deoxygenation degree of each heavy oil; the degree of deoxygenation (DOD) was estimated as follows.

Degree of deoxygenation (\%)

$$
=\left(\mathrm{MO}_{\text {bio-oil }}-\mathrm{MO}_{\text {heavyoil }}\right) / \mathrm{MO}_{\text {bio-oil }} \times 100
$$

Here, $\mathrm{MO}_{\text {heavy oil }}$ and $\mathrm{MO}_{\text {bio-oil }}$ are the molar oxygen/ carbon ratios of heavy oil and bio-oil.

\subsubsection{GC/MS analysis of low molecular compounds}

For measuring low-molecular-weight compounds in bio-oil and heavy oils qualitatively and quantitatively, GC/MS analysis was performed with fluoranthene as an internal standard. The analysis was conducted with an Agilent 7890B coupled with a 5975C mass selective detector (MSD) and a flame ionization detector (FID) equipped with a DB-5 capillary column (60 m × 0.25 $\mathrm{mm} \times 0.25 \mu \mathrm{m})$. The oven temperature was maintained at $50{ }^{\circ} \mathrm{C}$ for $5 \mathrm{~min}$, followed by heating at a rate of $3^{\circ} \mathrm{C} / \mathrm{min}$ to $280{ }^{\circ} \mathrm{C}$ and holding for $20 \mathrm{~min}$. The injector and FID detector temperatures were 250 and $300{ }^{\circ} \mathrm{C}$, respectively.

\section{RESULTS and DISCUSSION}

\subsection{Synthesis of bifunctional catalysts}

\subsubsection{Physical properties of the supports and bifunctional catalysts}

Table 1 presents the physical properties of the catalysts used in this study. The specific surface areas of NiFe/zeolite Y, NiFe/HBeta, and NiFe/ZSM-5 were 532.2, 545.1 and $316.5 \mathrm{~m}^{2} / \mathrm{g}$, while the pores volumes were $0.3,0.3$ and $0.2 \mathrm{~cm}^{3} / \mathrm{g}$, respectively. These values were lower than the supports themselves, which might be due to the metal loading (about 5 wt.\%). As shown in Fig. 1, zeolite supports were mono-layer support with micro-pores (Lippens 1965). Isothermal type of the supports presented that the zeolite supports have tubular with short necks, wide sloping bodies or various widths and the shape of pores remained after the metal impregnation. However, $\mathrm{CoMo} / \mathrm{Al}_{2} \mathrm{O}_{3}$ and $\mathrm{NiMo} / \mathrm{Al}_{2} \mathrm{O}_{3}$ were not clearly defined their pore type, since they presented type III physisorption isotherm, which meant 
Table 1. Characterization of supports and bifunctional catalysts

\begin{tabular}{ccccccc}
\hline Sample & $\begin{array}{c}\mathrm{SiO}_{2} / \mathrm{Al}_{2} \mathrm{O}_{3} \\
\text { Mole Ratio }^{\mathrm{a}}\end{array}$ & $\begin{array}{c}\mathrm{S}_{\mathrm{BET}} \mathrm{b} \\
\left(\mathrm{m}^{2} / \mathrm{g}\right)\end{array}$ & $\begin{array}{c}\mathrm{V}_{\mathrm{t}}^{\mathrm{c}} \\
\left(\mathrm{cm}^{3} / \mathrm{g}\right)\end{array}$ & $\begin{array}{c}\mathrm{V}_{\text {mic }}{ }^{\mathrm{d}} \\
\left(\mathrm{cm}^{3} / \mathrm{g}\right)\end{array}$ & $\begin{array}{c}\mathrm{V}_{\text {meso }} \\
\left(\mathrm{cm}^{3} / \mathrm{g}\right)\end{array}$ & $\begin{array}{c}\mathrm{D}_{\text {ave }} \\
(\AA)\end{array}$ \\
\hline \hline Zeolite Y & 5.2 & 697.4 & 0.4 & 0.3 & 0.1 & 2.1 \\
HBeta & 38 & 572.1 & 0.3 & 0.2 & 0.1 & 2.2 \\
ZSM-5 & 23 & 354.9 & 0.2 & 0.1 & 0.1 & 2.1 \\
NiFe/zeolite Y & 5.2 & 532.2 & 0.3 & 0.2 & 0.1 & 2.3 \\
NiFe/HBeta & 38 & 545.1 & 0.3 & 0.2 & 0.1 & 2.4 \\
NiFe/ZSM-5 & 23 & 316.5 & 0.2 & 0.1 & 0.1 & 2.4 \\
\hline
\end{tabular}

${ }^{\mathrm{a}}$ : Offered from the zeolyst company

${ }^{\mathrm{b}}$ : Calculated by the BET method

c: The total pore volume was obtained at a relative pressure of 0.99

d: Calculated using the $t$-plot method

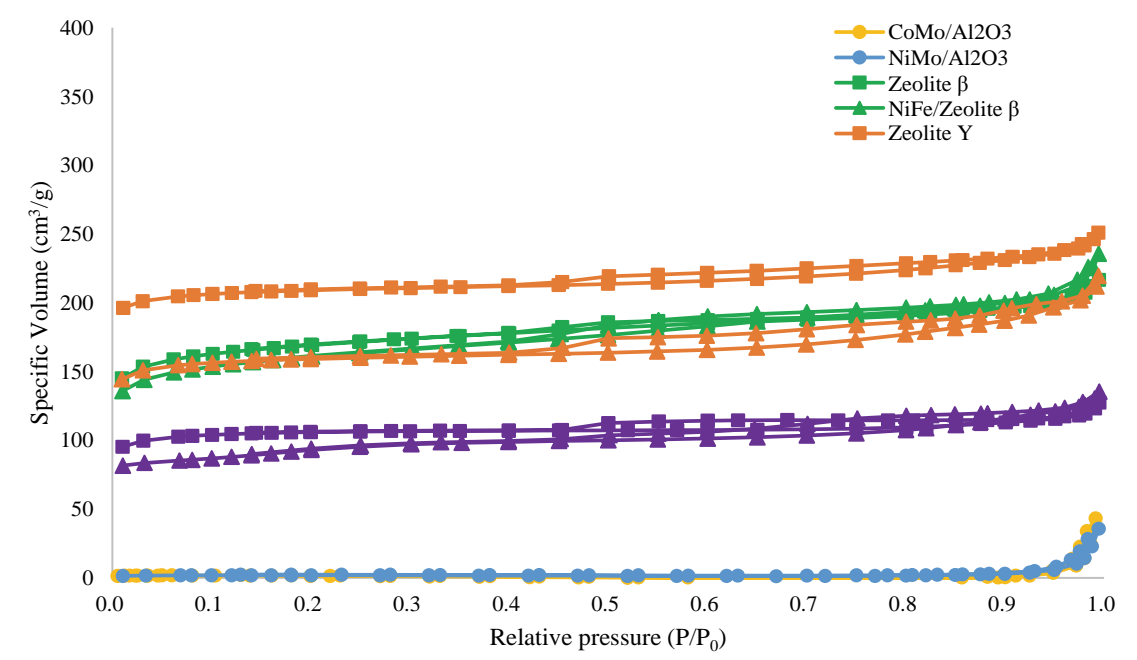

Fig. 1. Chemisorption features of the catalysts and supports.

weak adsorption interaction, and didn't match the hysteresis loops. Therefore, Zeolite supported bifunctional catalysts (NiFe/zeolite Y, NiFe/HBeta, and NiFe/ ZSM-5), with a high specific surface area and large pore, was expected to be effective for good dispersionof the reactant during the reaction. Compared with the zeolites and metal doped bifunctional catalysts, the pore diameter showed increase. It might be due to the crack of the pore during impregnation step (Munniket al., 2015).

\subsubsection{The morphologies of the supports and} $\mathrm{Ni}$ catalysts

The morphologies of the catalysts were investigated by SEM (Fig. 2). Commercial $\mathrm{CoMo} / \mathrm{Al}_{2} \mathrm{O}_{3}$ and $\mathrm{NiMo} / \mathrm{Al}_{2} \mathrm{O}_{3}$ showed smaller particles than prepared NiFe-based catalysts. Moreover, according to Fig. 2 (c)-(e), zeolite supports presented different particle shapes, despite their pore type (shape) and size were similar (Fig. 1 and Table 1). NiFe/ZSM-5, which has lower specific surface area $\left(316.5 \mathrm{~m}^{2} / \mathrm{g}\right)$ than other 

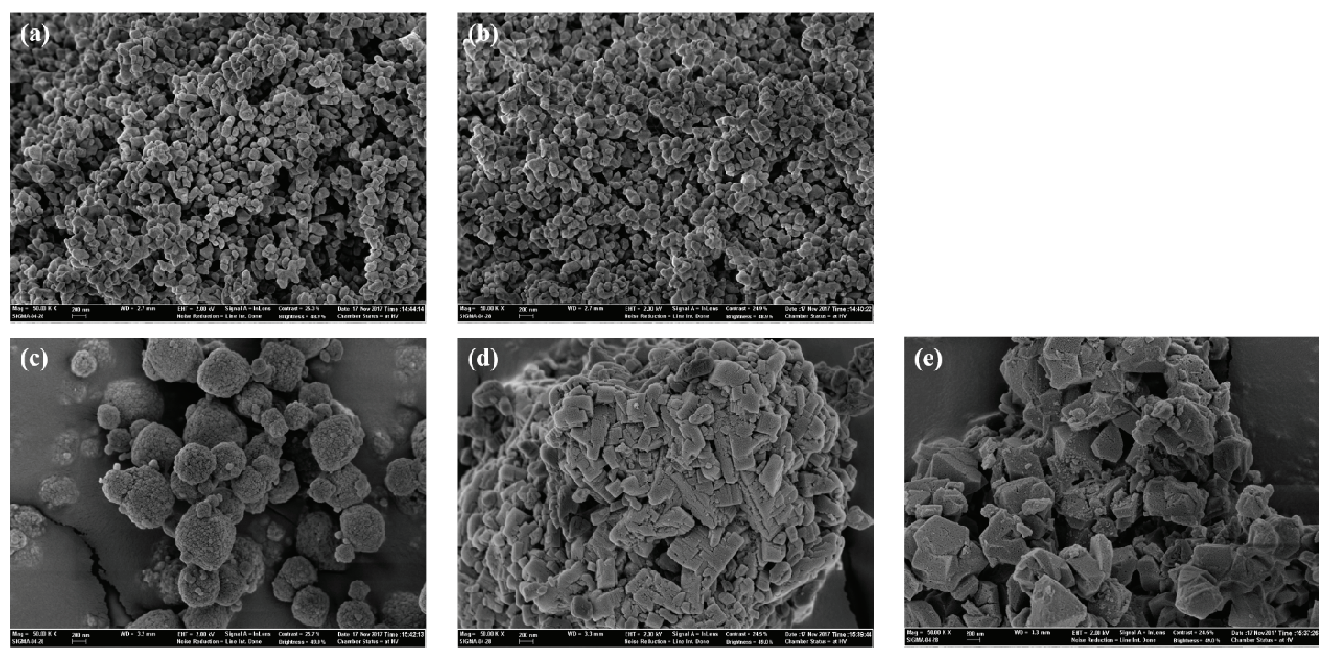

Fig. 2. SEM images of the prepared catalysts: (a) $\mathrm{NiMo} / \mathrm{Al}_{2} \mathrm{O}_{3}$; (b) $\mathrm{CoMo} / \mathrm{Al}_{2} \mathrm{O}_{3}$; (c) $\mathrm{NiFe} / \mathrm{HBeta}$; (d) NiFe/Zeolite Y; (e) NiFe/ZSM-5.
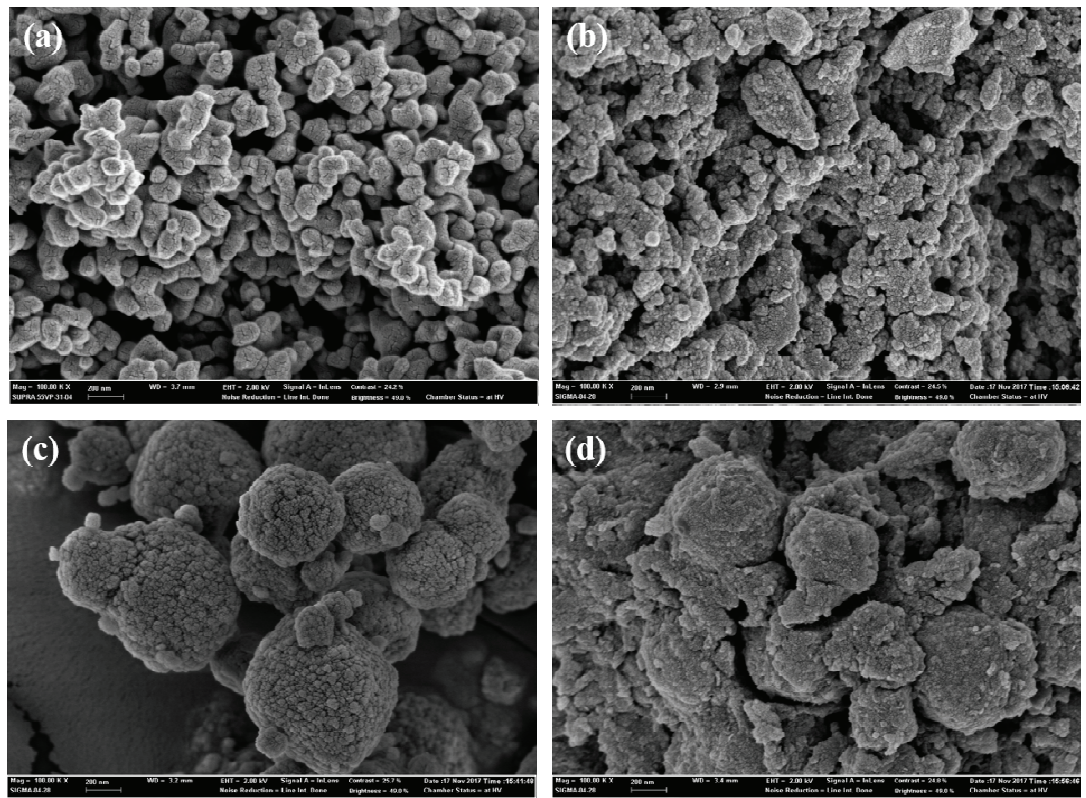

Fig. 3. Surface morphology of fresh and used catalysts: (a) fresh $\mathrm{NiMo} / \mathrm{Al}_{2} \mathrm{O}_{3}$; (b) used $\mathrm{NiMo} / \mathrm{Al}_{2} \mathrm{O}_{3}$; (c) fresh $\mathrm{NiFe} / \mathrm{HBeta}$; (d) used NiFe/HBeta.

zeolite supported bifunctional catalysts (ranged between 532.2 to $545.1 \mathrm{~m}^{2} / \mathrm{g}$ ) has rectangular large particles. While in Fig. 3, the catalysts were lost its original shape after the reaction. Some reactant and produced coke were deposited on the catalyst surface. It might deactivate the catalyst activity. 


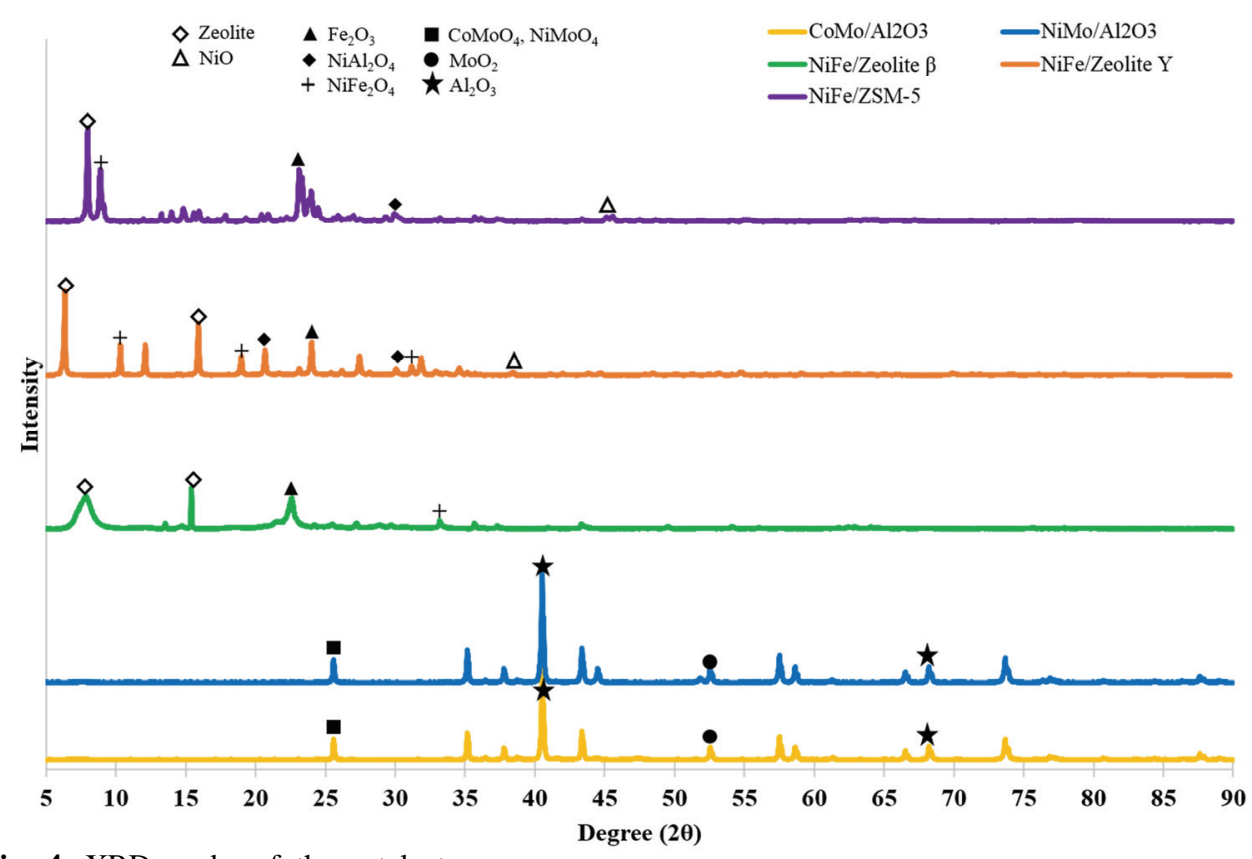

Fig. 4. XRD peaks of the catalysts.

\subsubsection{XRD patterns of the $\mathrm{Ni}$ catalysts}

The impregnation of NiFe over the zeolite supports led to the formation of bifunctional catalysts (NiFe/ zeolite $\mathrm{Y}, \mathrm{NiFe} / \mathrm{HBeta}$, and $\mathrm{NiFe} / \mathrm{ZSM}-5$ ) as well as led to the formation of metal oxide on the surface contained slight amount of crystalline aggregation as evidenced from the phase formation in the high angle XRD.

Fig. 4 presents the XRD peaks of $\mathrm{CoMo} / \mathrm{Al}_{2} \mathrm{O}_{3}$, $\mathrm{NiMo} / \mathrm{Al}_{2} \mathrm{O}_{3}, \mathrm{NiFe} /$ zeolite $\mathrm{Y}, \mathrm{NiFe} / \mathrm{HBeta}$, and NiFe/ ZSM-5. CoMo/ $/ \mathrm{Al}_{2} \mathrm{O}_{3}$ and $\mathrm{NiMo} / \mathrm{Al}_{2} \mathrm{O}_{3}$ presented three typical metal oxide peaks at $2 \theta=26^{\circ}$ and $53^{\circ}$, with $\mathrm{Al}_{2} \mathrm{O}_{3}$ support peaks at $2 \theta=41^{\circ}$ and $68^{\circ}$. Compared to $\mathrm{Al}_{2} \mathrm{O}_{3}$ supports, zeolites peaks detected in lower angle, such as $2 \theta=6-8^{\circ}$ and $16^{\circ}$ (Zhang et al., 2012; Hunter et al., 2016). Moreover, differed zeolite resulted in different metal oxide forms; mainly consist of $\mathrm{NiFe}_{2} \mathrm{O}_{4}$ in $\mathrm{NiFe}$ /zeolite $\mathrm{Y}$ while $\mathrm{NiAl}_{2} \mathrm{O}_{4}$ and $\mathrm{Fe}_{2} \mathrm{O}_{3}$ in $\mathrm{NiFe} /$ ZSM-5.

\subsection{Catalytic activity}

To test and compare the HDO activity of catalysts, HDO of waste wood bio-oil was conducted with those catalysts. The bio-oil was converted and produced heavy oil, light oil, char and gas. The yields of the HDO products obtained with different temperature and solvent concentration are shown in Tables 2-3 based on the weight of the bio-oil. The yield of each product revealed that the composition of the HDO products was considerably affected by the zeolite supports. Compared the data from three different supports (NiFe/HBeta, NiFe/zeolite $\mathrm{Y}$ and NiFe/ZSM-5), HBeta support showed thermally stable features according to the heavy oil yield from 300 to $400{ }^{\circ} \mathrm{C}$ (18.3-18.9 wt\%). However, the char and gas strikingly increased with temperature, which meant both further decomposition by temperature and catalyst deactivation by coke deposition on surface are accelerated. Both NiFe/zeolite Y and NiFe/ZSM-5 showed the tendency of decrease heavy oil and light 
Effect of Different Zeolite Supported Bifunctional Catalysts for Hydrodeoxygenation of Waste Wood Bio-oil

Table 2. Mass balance of main products with different HDO temperature (25 wt\% of ethanol)

\begin{tabular}{|c|c|c|c|c|c|}
\hline \multirow{2}{*}{\multicolumn{2}{|c|}{ Temperature $\left({ }^{\circ} \mathrm{C}\right)$}} & \multicolumn{4}{|c|}{ Yield (wt\%) } \\
\hline & & \multirow{2}{*}{$\begin{array}{l}\text { Heavy oil } \\
22.9(0.7)\end{array}$} & \multirow{2}{*}{$\begin{array}{c}\text { Light oil } \\
34.9(2.3)\end{array}$} & \multirow{2}{*}{$\begin{array}{c}\text { Char } \\
20.6(1.4)\end{array}$} & \multirow{2}{*}{$\frac{\text { Gas }}{21.6(1.5)}$} \\
\hline & 300 & & & & \\
\hline \multirow[t]{3}{*}{$\mathrm{CoMo} / \mathrm{Al}_{2} \mathrm{O}_{3}$} & 350 & $20.7(0.5)$ & $38.4(2.8)$ & 24.9 (3.5) & $16.0(0.7)$ \\
\hline & 400 & $14.8(1.4)$ & $35.9(2.4)$ & 24.7 (2.7) & $24.6(2.0)$ \\
\hline & 300 & $26.1(1.3)$ & $35.9(1.3)$ & $25.6(2.5)$ & $12.5(1.2)$ \\
\hline \multirow[t]{3}{*}{$\mathrm{NiMo} / \mathrm{Al}_{2} \mathrm{O}_{3}$} & 350 & $24.7(0.8)$ & $39.1(0.3)$ & $21.1(2.2)$ & $15.0(1.8)$ \\
\hline & 400 & $18.2(0.1)$ & $40.2(2.1)$ & 22.7 (3.9) & $18.9(1.9)$ \\
\hline & 300 & $21.0(1.3)$ & $29.9(2.6)$ & $18.7(1.3)$ & 30.4 (3.6) \\
\hline \multirow[t]{3}{*}{ NiFe/zeolite Y } & 350 & $19.5(0.3)$ & $23.9(0.8)$ & $25.3(1.1)$ & $31.2(2.4)$ \\
\hline & 400 & $17.8(0.8)$ & $23.3(2.1)$ & $24.6(1.9)$ & $34.4(3.0)$ \\
\hline & 300 & $18.3(0.1)$ & $34.8(1.1)$ & $21.2(2.1)$ & $25.6(3.0)$ \\
\hline \multirow[t]{3}{*}{ NiFe/HBeta } & 350 & $18.9(0.2)$ & $29.2(2.3)$ & $28.1(4.5)$ & $23.8(2.4)$ \\
\hline & 400 & $18.9(0.7)$ & $23.7(0.3)$ & $29.3(2.9)$ & $28.0(3.1)$ \\
\hline & 300 & $28.2(0.5)$ & 37.4 (1.5) & $17.2(2.1)$ & $17.3(1.2)$ \\
\hline \multirow[t]{2}{*}{ NiFe/ZSM-5 } & 350 & $23.0(0.8)$ & 24.7 (2.6) & $14.6(1.6)$ & $37.6(2.5)$ \\
\hline & 400 & $20.0(2.5)$ & $23.5(2.3)$ & 14.0 & $42.5(4.1)$ \\
\hline
\end{tabular}

Table 3. Mass balance of main products with different ethanol concentration (under $350{ }^{\circ} \mathrm{C}$ )

\begin{tabular}{|c|c|c|c|c|c|}
\hline \multirow{2}{*}{\multicolumn{2}{|c|}{ Temperature $\left({ }^{\circ} \mathrm{C}\right)$}} & \multicolumn{4}{|c|}{ Yield (wt\%) } \\
\hline & & Heavy oil & Light oil & Char & Gas \\
\hline \multirow{3}{*}{$\mathrm{CoMo} / \mathrm{Al}_{2} \mathrm{O}_{3}$} & 25 & $20.7(0.2)$ & $28.4(2.1)$ & $24.9(1.1)$ & $26.0(2.7)$ \\
\hline & 10 & $17.5(1.6)$ & $25.8(1.3)$ & $28.7(1.4)$ & $28.0(2.5)$ \\
\hline & 5 & $18.4(1.1)$ & $20.9(2.7)$ & $37.1(0.4)$ & $23.6(1.8)$ \\
\hline \multirow{3}{*}{$\mathrm{NiMo} / \mathrm{Al}_{2} \mathrm{O}_{3}$} & 25 & $24.7(0.4)$ & $29.1(2.8)$ & 21.9 (1.6) & $24.2(1.7)$ \\
\hline & 10 & $22.3(1.9)$ & 26.7 (3.6) & 30.5 (1.3) & 20.5 (1.3) \\
\hline & 5 & $20.8(0.6)$ & $21.2(1.7)$ & $30.8(2.9)$ & $27.2(2.6)$ \\
\hline \multirow{3}{*}{ NiFe/zeolite Y } & 25 & $19.5(0.7)$ & $23.9(1.7)$ & $25.3(2.1)$ & 31.2 (1.7) \\
\hline & 10 & $17.5(0.9)$ & $29.0(2.1)$ & $28.6(1.0)$ & $25.0(2.2)$ \\
\hline & 5 & $19.9(1.3)$ & $22.8(0.8)$ & 30.9 (1.3) & $26.4(3.6)$ \\
\hline \multirow{3}{*}{ NiFe/HBeta } & 25 & $18.9(1.0)$ & $29.2(0.4)$ & $28.1(0.9)$ & $23.8(2.1)$ \\
\hline & 10 & $18.3(0.8)$ & $30.5(1.0)$ & 30.4 (1.6) & $20.8(2.5)$ \\
\hline & 5 & $18.3(0.1)$ & $30.0(1.9)$ & $31.5(2.1)$ & $20.2(2.4)$ \\
\hline \multirow{3}{*}{ NiFe/ZSM-5 } & 25 & $23.0(1.5)$ & $24.7(1.5)$ & $14.6(2.1)$ & $37.6(2.0)$ \\
\hline & 10 & $19.3(2.2)$ & $25.3(1.7)$ & $15.8(0.2)$ & 39.5 (1.1) \\
\hline & 5 & $14.3(1.9)$ & $27.4(2.1)$ & $23.6(1.8)$ & 34.7 (1.4) \\
\hline
\end{tabular}

oil and strikingly increase in gas, while the char decrease in NiFe/ZSM-5 and increase in NiFe/zeolite Y. While the NiFe/HBeta, which has high specific surface area with high $\mathrm{Si} / \mathrm{Al}$ ratio (Table 1 ), showed similar products yield with varied reaction conditions (Tables 2-3). According to the results, it is suggested that the catalyst high $\mathrm{Si} / \mathrm{Al}$ ratio could inhibit the catalyst deactivation. 
In case of commercial $\mathrm{CoMo} / \mathrm{Al}_{2} \mathrm{O}_{3}$ and $\mathrm{NiMo} / \mathrm{Al}_{2} \mathrm{O}_{3}$, the gas yield (12.5-21.6 wt\%) is lower than that from zeolite supported bifunctional catalysts (17.3-42.5 wt\%) with similar yield of heavy oil. It is suggested that these $\mathrm{CoMo} / \mathrm{Al}_{2} \mathrm{O}_{3}$ and $\mathrm{NiMo} / \mathrm{Al}_{2} \mathrm{O}_{3}$ catalysts deactivated less than $\mathrm{NiFe} /$ zeolite $\mathrm{Y}, \mathrm{NiFe} / \mathrm{HBeta}$, and $\mathrm{NiFe} /$ ZSM-5, which prevented that the further decomposition by the temperature.

As shown in Table 3, the heavy oil yielded less in lower concentration of ethanol. Since the waste wood bio-oil itself was too sticky $\left(103 \mathrm{~mm}^{2} / \mathrm{s}\right.$, Tables 4-5), it produced huge amount of sticky tar-like char (14.6- $37.1 \mathrm{wt} \%$ ). Also, these were affected by the particle size and specific surface area (Table 1). Small particle size with large specific surface area led frequent efficient collision, but in the batch type reactor, sticky feature of the bio-oil might not let the catalysts regenerated.

\subsection{Fuel properties of heavy oil}

\subsubsection{Physicochemical features of heavy oi}

Typical fuel properties, such as acidity, heating value, and thermal stability, are improved in heavy oil after HDO via hydrocracking, hydrogenolysis, dehydration, hydrogenation and deoxygenation (Furimsky et al., 1986). Therefore, several improved physicochemical properties of heavy oil were measured and are displayed in Tables 4-5. The water content, which is major feature related to the heating value and combustion properties in the engine, is $19.3 \%$ in the waste wood bio-oil and decreased to 3.1-16.6 wt\% in the heavy oils, via dehydration of the organic phase. Since the metal site of commercial catalysts, involved in dehydration well remained $\mathrm{H}_{2}$-reduced state, $\mathrm{CoMo} / \mathrm{Al}_{2} \mathrm{O}_{3}$ and $\mathrm{NiMo} /$ $\mathrm{Al}_{2} \mathrm{O}_{3}$ worked better than prepared bifunctional catalysts (even though the zeolites are known as good at dehydration). The zeolites with high acidity (also

Table 4. Physicochemical properties of the heavy oils with $25 \mathrm{wt} \%$ of ethanol

\begin{tabular}{|c|c|c|c|c|c|c|c|c|c|c|c|c|c|c|c|c|}
\hline & \multirow{3}{*}{ Bio-oil } & \multicolumn{3}{|c|}{$\mathrm{CoMo} / \mathrm{Al}_{2} \mathrm{O}_{3}$} & \multicolumn{3}{|c|}{$\mathrm{NiMo} / \mathrm{Al}_{2} \mathrm{O}_{3}$} & \multicolumn{3}{|c|}{ NiFe/zeolite Y } & \multicolumn{3}{|c|}{$\mathrm{NiFe} / \mathrm{HBeta}$} & \multicolumn{3}{|c|}{ NiFe/ZSM-5 } \\
\hline & & \multicolumn{15}{|c|}{ Temperature $\left({ }^{\circ} \mathrm{C}\right)$} \\
\hline & & 300 & 350 & 400 & 300 & 350 & 400 & 300 & 350 & 400 & 300 & 350 & 400 & 300 & 350 & 400 \\
\hline Water content (wt\%) & 19.3 & 5.2 & 5.0 & 3.1 & 4.6 & 4.9 & 3.8 & 10.0 & 7.3 & 9.2 & 5.0 & 12.0 & 10.6 & 7.3 & 13.0 & 16.6 \\
\hline $\begin{array}{c}\text { TAN } \\
\text { (mg KOH/g oil) }\end{array}$ & 150 & 28 & 31 & 52 & 56 & 50 & 70 & 62 & 52 & 56 & 28 & 47 & 55 & 77 & 73 & 58 \\
\hline Viscosity $\left(\mathrm{mm}^{2} / \mathrm{s}\right)^{\mathrm{a}}$ & 103 & 57 & 65 & 58 & 62 & 67 & 69 & 40 & 46 & 44 & 45 & 43 & 49 & 42 & 48 & 46 \\
\hline \multicolumn{17}{|c|}{ Elemental analysis (dry basis, wt\%) } \\
\hline $\mathrm{C}$ & 42.9 & 67.7 & 65.3 & 68.7 & 60.5 & 62.7 & 64.0 & 62.6 & 68.1 & 67.6 & 56.9 & 59.7 & 60.3 & 58.0 & 66.8 & 65.4 \\
\hline $\mathrm{H}$ & 7.1 & 7.5 & 8.6 & 8.7 & 10.0 & 9.9 & 8.7 & 8.3 & 8.2 & 8.8 & 9.5 & 8.7 & 9.1 & 7.9 & 8.1 & 9.9 \\
\hline $\mathrm{N}$ & $<0.1$ & $<0.1$ & - & - & - & - & - & $<0.1$ & - & - & - & - & - & - & - & - \\
\hline $\mathrm{O}^{\mathrm{b}}$ & 49.9 & 24.7 & 26.1 & 22.6 & 29.5 & 27.4 & 27.3 & 29.0 & 23.7 & 23.6 & 33.6 & 31.6 & 30.6 & 34.1 & 25.1 & 24.7 \\
\hline $\mathrm{S}$ & $<0.1$ & 0.1 & - & - & - & - & - & - & - & - & - & - & - & - & - & - \\
\hline $\begin{array}{c}\text { HHV } \\
\text { (MJ/kg, dry basis) }\end{array}$ & 13.7 & 28.2 & 28.1 & 31.2 & 26.5 & 27.8 & 27.9 & 24.3 & 28.3 & 27.9 & 23.8 & 22.4 & 23.5 & 22.6 & 25.1 & 24.7 \\
\hline $\begin{array}{c}\text { Degree of } \\
\text { deoxygenation }\end{array}$ & - & 50.5 & 47.7 & 54.7 & 40.9 & 45.1 & 45.3 & 41.9 & 52.5 & 52.7 & 32.7 & 36.7 & 38.7 & 31.7 & 49.7 & 50.5 \\
\hline
\end{tabular}

${ }^{\mathrm{a}}$ : Measured at $20^{\circ} \mathrm{C}$

${ }^{\mathrm{b}}$ : Calculated by difference 
Effect of Different Zeolite Supported Bifunctional Catalysts for Hydrodeoxygenation of Waste Wood Bio-oil

Table 5. Physicochemical properties of the heavy oils under $350{ }^{\circ} \mathrm{C}$

\begin{tabular}{|c|c|c|c|c|c|c|c|c|c|c|c|c|c|c|c|c|}
\hline & \multirow{3}{*}{ Bio-oil } & \multicolumn{3}{|c|}{$\mathrm{CoMo} / \mathrm{Al}_{2} \mathrm{O}_{3}$} & \multicolumn{3}{|c|}{$\mathrm{NiMo} / \mathrm{Al}_{2} \mathrm{O}_{3}$} & \multicolumn{3}{|c|}{ NiFe/zeolite Y } & \multicolumn{3}{|c|}{ NiFe/HBeta } & \multicolumn{3}{|c|}{ NiFe/ZSM-5 } \\
\hline & & \multicolumn{15}{|c|}{ Concentration (wt\%) } \\
\hline & & 25 & 10 & 5 & 25 & 10 & 5 & 25 & 10 & 5 & 25 & 10 & 5 & 25 & 10 & 5 \\
\hline Water content (wt\%) & $\begin{array}{l}19.3 \\
(0.2)\end{array}$ & 5.0 & 3.8 & 4.2 & 4.9 & 5.2 & 4.3 & 7.3 & 9.5 & 15.6 & 12.0 & 10.9 & 8.3 & 13.0 & 8.4 & 8.3 \\
\hline $\begin{array}{c}\text { TAN } \\
\text { (mg KOH/g oil) }\end{array}$ & $\begin{array}{l}150 \\
(1.3)\end{array}$ & 31 & 68 & 70 & 70 & 54 & 78 & 52 & 50 & 52 & 47 & 60 & 59 & 73 & 70 & 68 \\
\hline $\operatorname{Viscosity}\left(\mathrm{mm}^{2} / \mathrm{s}\right)^{\mathrm{a}}$ & 103 & 65 & 82 & 86 & 67 & 73 & 84 & 46 & 64 & 68 & 43 & 59 & 67 & 48 & 52 & 59 \\
\hline \multicolumn{17}{|c|}{ Elemental analysis (dry basis, wt\%) } \\
\hline $\mathrm{C}$ & 42.9 & 65.3 & 67.5 & 67.4 & 62.7 & 63.4 & 62.2 & 68.1 & 63.8 & 57.0 & 59.7 & 61.4 & 62.5 & 66.8 & 63.3 & 65.2 \\
\hline $\mathrm{H}$ & 7.1 & 8.6 & 8.2 & 10.0 & 9.9 & 8.5 & 8.6 & 8.2 & 8.7 & 9.3 & 8.7 & 8.7 & 8.7 & 8.1 & 8.5 & 8.1 \\
\hline $\mathrm{N}$ & $<0.1$ & - & - & - & - & - & - & - & - & - & - & - & - & - & $<0.1$ & - \\
\hline $\mathrm{O}^{\mathrm{b}}$ & 49.9 & 26.1 & 24.3 & 32.5 & 27.4 & 28.1 & 29.2 & 23.7 & 27.5 & 33.7 & 31.6 & 29.9 & 28.8 & 25.1 & 28.1 & 26.7 \\
\hline $\mathrm{S}$ & $<0.1$ & - & - & - & - & - & - & - & - & - & - & - & - & - & - & - \\
\hline $\begin{array}{c}\text { HHV } \\
\text { (MJ/kg, dry basis) }\end{array}$ & 13.7 & 28.1 & 29.5 & 31.4 & 27.8 & 26.7 & 26.5 & 28.3 & 25.5 & 20.4 & 22.4 & 23.7 & 25.2 & 25.1 & 25.5 & 26.2 \\
\hline $\begin{array}{c}\text { Degree of } \\
\text { deoxygenation }\end{array}$ & - & 47.7 & 51.3 & 54.7 & 45.1 & 43.7 & 41.5 & 52.5 & 44.9 & 32.5 & 36.7 & 40.1 & 42.3 & 49.7 & 43.7 & 46.5 \\
\hline
\end{tabular}

${ }^{\mathrm{a}}$ : Measured at $20^{\circ} \mathrm{C}$

${ }^{\mathrm{b}}$ : Calculated by difference

concerned with dehydration reaction) also worked for reducing water content. But the zeolite framework structure tends to collapse under high temperature (Blakeman et al., 2014), the water content of heavy oil increased again in $400{ }^{\circ} \mathrm{C}$. Moreover, the mesoporous alumina-silica support (e.g. MCM-41, SBA-15 etc.) presented higher dehydration than microporous catalysts (Shemfe et al., 2017). However, the zeolites used in this study had similar pore size and pore volume, the acidity ( $\mathrm{Si} / \mathrm{Al}$ ratio) would be highly affected to dehydration. While the solvent concentration presented not that notable effect on the variation of water content (Table 5).

The TAN of the heavy oil was significantly reduced (28-77 $\mathrm{mg} \mathrm{KOH} / \mathrm{g}$ oil) in comparison to that of waste woo bio-oil (150mg KOH/g oil). Despite acid removal, phenolic compounds should be measured as a weak acid by $\mathrm{KOH}$. Therefore, the heavy oils still showed certain level of acidity. Viscosity is also the important factor when the fuel injected into an engine (Ochoa-
Hernández et al., 2013). In this experiment, the viscosity of waste wood bio-oil decreased from $103 \mathrm{~mm}^{2} / \mathrm{s}$ to $43-86 \mathrm{~mm}^{2} / \mathrm{s}$ in heavy oils. This assumed that the catalysts could effectively convert the macromolecular compounds consisted of bio-oil into monomeric or low molecular compounds in the heavy oils.

\subsubsection{Calorific value and Van Krevelen diagram of the heavy oil}

The elemental compositions of the waste wood bio-oil and heavy oil were determined and are presented in Tables 4-5. Compared to the carbon (42.9 wt\%), hydrogen (7.1 wt\%), and oxygen (49.9 wt\%) contents of the waste wood bio-oil, the carbon and hydrogen levels increased (57.0-68.7 wt\%, and 7.5-10.0 wt\%, respectively), while the oxygen level decreased (22.6-34.1 wt\%) in heavy oils. Nitrogen and sulfur was not detected in almost of all the heavy oils, while some heavy oil contains less than $0.1 \mathrm{wt} \%$. High carbon content and hydrogen content with low oxygen content resulted in high higher 
heating value (HHV). The HHV was calculated with the equation from previous study (Friedl et al., 2005) using dry basis $\mathrm{C}, \mathrm{H}$, and $\mathrm{N}$ contents. As a result, $\mathrm{HHV}$ of $13.7 \mathrm{MJ} / \mathrm{kg}$ (waste wood bio-oil) enhanced 22.6-31.2 $\mathrm{MJ} / \mathrm{kg}$ in heavy oils.

The heavy oil obtained from $400{ }^{\circ} \mathrm{C}$ with CoMo/ $\mathrm{Al}_{2} \mathrm{O}_{3}$ presented the highest carbon content and the lowest oxygen level among those heavy oils, resulting in the highest HHV. However, despite the high carbon content in the heavy oils obtained from lower solvent concentration, the oxygen level also high due to the catalyst deactivation, resulted in lower HHV than the $25 \mathrm{wt} \%$ solvent mixture as a raw material.

In Fig. 5, the Van Krevelen diagram, consisted of atomic $\mathrm{O} / \mathrm{C}$ and $\mathrm{H} / \mathrm{C}$ ratio to easily compare the deoxygenation and hydrogenation after the HDO reaction, of the bio-oil, and heavy oils was described. The atomic ratio of waste wood bio-oil (0.6) decreased ranged from 0.1-0.4. The lowest $\mathrm{O} / \mathrm{C}$ ratio (0.1) was investigated in the heavy oil obtained from $400{ }^{\circ} \mathrm{C}$ with NiFe/ZSM-5. Zeolite supported bifunctional catalysts showed the tendency of decreasing the atomic $\mathrm{O} / \mathrm{C}$ ratio with temperature, while CoMo/ $\mathrm{Al}_{2} \mathrm{O}_{3}$ and $\mathrm{NiMo} / \mathrm{Al}_{2} \mathrm{O}_{3}$ didn't presented the trend with temperature. While some conditions reduce even the $\mathrm{H} / \mathrm{C}$ ratio of waste wood bio-oil (1.4) to 1.2-1.4. NiFe/HBeta under $300{ }^{\circ} \mathrm{C}$ HDO presented $\mathrm{H} / \mathrm{C}$ ratio of 1.9 . When the bio-oil hydrodeoxygenated with this NiFe/HBeta, both hydrogenation and deoxygenation performed well (0.3-0.4 of $\mathrm{O} / \mathrm{C}$ ratio and 1.5-1.9 of $\mathrm{H} / \mathrm{C}$ ratio, respectively). Also $\mathrm{NiMo} / \mathrm{Al}_{2} \mathrm{O}_{3}$ presented well hydrogenation (higher $\mathrm{H} / \mathrm{C}$ ratio than that of waste wood bio-oil; 1.5-1.9).

\subsection{Degree of deoxygenation (DOD)}

As mentioned in previous section, high oxygen levels result in high acidity, viscosity, and low heating values, deoxygenation is the most important to the value-added utilization of bio-oil. During HDO process, deoxygenation, such as demethoxylation, dehydroxylation, or dehydration simultaneously occurred and led to decrease oxygen levels in bio-oil. The DOD was calculated based on the atomic $\mathrm{O} / \mathrm{C}$ ratio. After the $\mathrm{HDO}$, the $\mathrm{O} / \mathrm{C}$ ratio of the bio-oil (0.6) decreased to 0.1-0.4 due to deoxygenation. There were no significant differences among the HDO temperature, except for

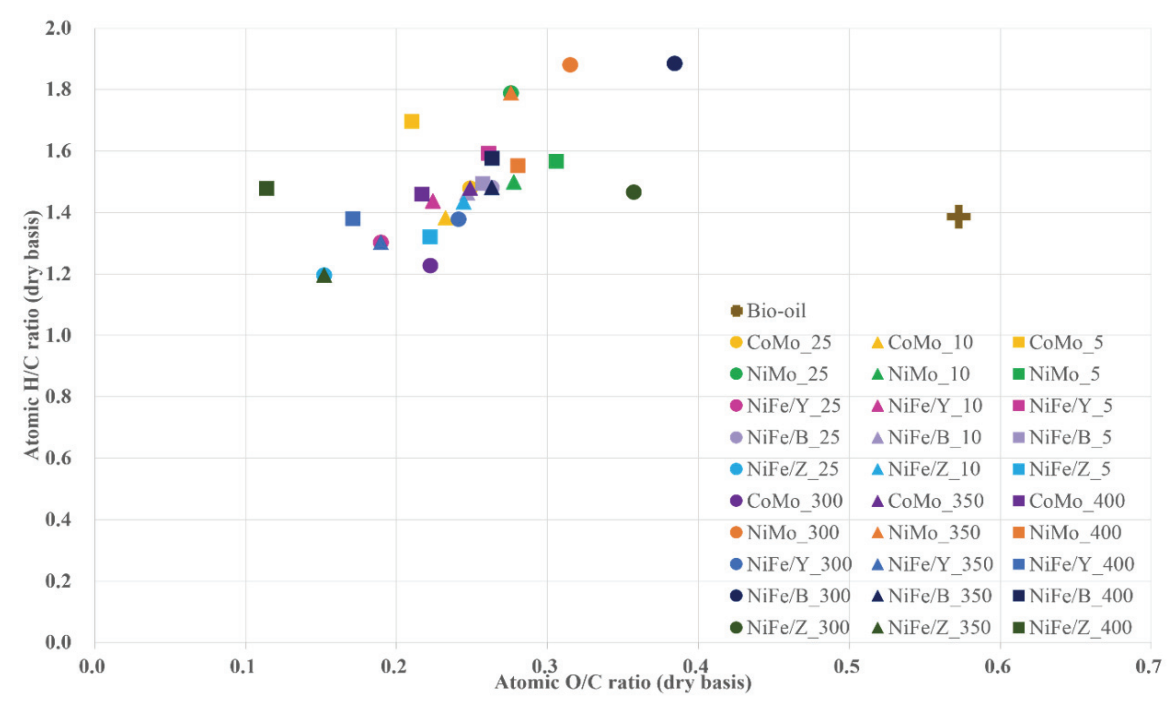

Fig. 5. Van Krevelen diagram of the heavy oil. 
Effect of Different Zeolite Supported Bifunctional Catalysts for Hydrodeoxygenation of Waste Wood Bio-oil

using the NiFe/ZSM-5 catalyst. This catalyst has the smaller pore diameter, and when the temperature increased, some part of framework collapsed, but might retain its features to maintain metal active sites involved in deoxygenation. When the solvent concentration varied, $\mathrm{NiFe}$ / zeolite $\mathrm{Y}$ and $\mathrm{NiFe} / \mathrm{HBeta}$ showed opposite trend. It seemed to be due to coke deposition on the surface pore. High specific surface area of NiFe/HBeta was deactivated by coke and the NiFe/HBeta catalyst became aggregated. So it might not have change to collapse the zeolite framework (Chen et al., 1997). The trend is same in the water content, so it is clear that the acid sites of these catalysts related to the dehydration.

\subsection{Structural modification of low-molecular weight compounds during HDO}

Typical compounds in bio-oil and heavy oils were identified from the GC/MS analysis and classified based on chemical structure and functional groups. Their relative amounts are presented in Table 6 .

The generated compounds in heavy oil mainly consisted as phenolic compounds, such as phenol, cresol

Table 6. Chemical distributions of heavy oil (350 ${ }^{\circ} \mathrm{C}, 25$ wt\% ethanol)

\begin{tabular}{|c|c|c|c|c|c|c|c|}
\hline \multirow{2}{*}{ RT } & \multirow{2}{*}{ Compound } & \multicolumn{6}{|c|}{ Relative area } \\
\hline & & Bio-oil & $\mathrm{CoMo} / \mathrm{Al}_{2} \mathrm{O}_{3}$ & $\mathrm{NiMo} / \mathrm{Al}_{2} \mathrm{O}_{3}$ & NiFe/HBeta & NiFe/zeolite $\mathrm{Y}$ & NiFe/ZSM-5 \\
\hline \multicolumn{8}{|c|}{ Acids } \\
\hline 3.3 & Acetic acid & 3.5 & - & - & - & - & - \\
\hline \multicolumn{8}{|c|}{ Esters } \\
\hline 3.4 & Acetic acid, ethyl ester & - & 1.7 & 1.8 & 1.7 & 2.9 & 2.1 \\
\hline \multicolumn{8}{|c|}{ Ketones } \\
\hline 11.6 & 2-Methyl-2-cyclopenten-1-one & - & 0.3 & 0.4 & 0.2 & 0.4 & 0.4 \\
\hline 12.0 & Dihydropyran & 0.4 & 0.4 & 0.1 & 0.3 & 0.4 & 0.0 \\
\hline 12.5 & 2(5H)-Furanone & 0.1 & 0.0 & 0.3 & 0.0 & 0.1 & 0.1 \\
\hline 18.0 & 2,3-Dimethyl-cyclopenten-1-one & 0.6 & 0.0 & 0.4 & 0.0 & 0.5 & 0.1 \\
\hline \multicolumn{8}{|c|}{ Aldehydes } \\
\hline 35.4 & Vanillin & 0.6 & 0.0 & 0.0 & 0.0 & 0.0 & 0.0 \\
\hline 43.1 & Syringaldehyde & 0.8 & 0.0 & 0.0 & 0.0 & 0.0 & 0.0 \\
\hline \multicolumn{8}{|c|}{ Alcohols } \\
\hline 45.2 & Dihydro-coniferylalcohol & 0.2 & 0.0 & 0.0 & 0.0 & 0.0 & 0.0 \\
\hline \multicolumn{8}{|c|}{ Sugars } \\
\hline 39.7 & Levoglucosan & 2.9 & 0.0 & 0.0 & 0.0 & 0.0 & 0.0 \\
\hline \multicolumn{8}{|c|}{ Phenols } \\
\hline 15.8 & Phenol & 0.3 & 1.0 & 1.0 & 1.0 & 0.7 & 0.8 \\
\hline 19.2 & Cresol & 0.4 & 1.2 & 1.1 & 1.2 & 0.7 & 1.5 \\
\hline 20.5 & Guaiacol & 0.5 & 1.4 & 1.5 & 1.4 & 0.9 & 0.7 \\
\hline 25 & 4-Ethyl-phenol & - & 0.1 & 0.2 & 0.2 & 0.1 & 0.2 \\
\hline 25.7 & 4-Methyl-guaiacol & - & 0.3 & 0.1 & 3.3 & 0.2 & 3.1 \\
\hline 29.5 & 4-Ethyl-guaiacol & 0.3 & 0.9 & 0.6 & 0.5 & 0.3 & 0.4 \\
\hline 32.9 & Syringol & - & 0.2 & 0.2 & 0.1 & 0.3 & 0.3 \\
\hline 33.1 & 2,4-Dimethoxyphenol & - & 0.1 & 0.1 & 0.1 & 0.0 & 0.1 \\
\hline 33.4 & 4-Propyl-guaiacol & 0.5 & 0.4 & 0.4 & 0.4 & 0.2 & 0.2 \\
\hline 36.9 & 4-Methyl-syringol & 1.8 & 0.6 & 0.3 & 0.6 & 0.6 & 0.6 \\
\hline 37.1 & 4-Propenyl-guaiacol & 0.6 & 0.2 & 0.1 & 0.2 & 0.2 & 0.3 \\
\hline 43.1 & 4-Propyl-syringol & - & 0.1 & 0.0 & 0.2 & 0.2 & 0.2 \\
\hline & Total & 13.6 & 8.9 & 8.6 & 11.5 & 8.6 & 11.1 \\
\hline
\end{tabular}


and guaiacol. The minor compounds, such as esters, ketones, and other phenolic compounds, were also present in heavy oils after the HDO. The heavy oils showed a $15.4-36.8 \%$ decrease in the total compounds compared to bio-oil. The decrease typically resulted from decarboxylation and further decomposition of acetic acid, vanillin, syringaldehyde and levoglucosan. According to previous study (Oh et al., 2017), acetic acid which was not converted into ethyl ester form, remained and separated in the light oil phase.

Generation of cresol and removal of alkyl-guaiacol suggest that catalysts can accelerate dealkylation or transalkylation. However, the remaining alkyl-guaiacol and alkyl-syringol as well as producion of 4-propylsyringol suggest that NiFe-based catalysts might not totally effective for reducing the activation energy of dealkylation, or decomposition. Moreover, abundant guaiacol and small amount of syringol remained in the heavy oil, despite demethoxylation to phenol. This result was due to the dealkylation, or demethoxylation via hydrogenation (Furimsky et al., 1986). The unstable and undesired oxygenated compounds in the bio-oil, such as acetic acid, vanillin and levoglucosan which could perform repolymerization during the reaction, were effectively converted into acetic acid ethyl esters, 2-methyl-2-cyclopenten-1-one, or 2(5H)-Furanone in the heavy oil via hydrogenation, decarbonylation, dehydroxylation, and ring opening, or low molecular gas phase. However, compared with previous study with mesoporous catalysts (Oh et al., 2017), the total amount of Furans were less in this results. It might be due to the different composition of bio-oil as well as the varied metal sites (from previously studied monometallic Ni (Oh et al., 2017) to Mo-based and bimetallic NiFe-based catalysts in this study).

\section{CONCLUSION}

In this study, the HDO of waste wood bio-oil using two commercial and three prepared bifunctional catalysts in batch type reactor were investigated. The porous zeolite supported NiFe-based catalysts yielded lower heavy oil than non-porous Mo-based catalysts. NiFe/ZSM-5, has the lowest specific surface area notably affected by temperature and solvent concentration. While, the fuel properties of heavy oil improved through HDO. Especially HHV of the heavy oil from CoMo/ $\mathrm{Al}_{2} \mathrm{O}_{3}$ under $400{ }^{\circ} \mathrm{C}$, were even more improved $56.1 \%$ than bio-oil. Considering with HHV and the heavy oil yield, the NiFe/zeolite $\mathrm{Y}$, has higher specific surface area and low $\mathrm{Si} / \mathrm{Al}$ ratio presented the most improved quality heavy oilat high temperature, while the solvent concentration slightly affected to the quality.

\section{ACKNOWLEDGMENT}

This work was supported by the Basic Science Research Program of the National Research Foundation, funded by the Ministry of Education, Science and Technology [NRF-2017R1A2B4002003].

\section{REFERENCES}

Ardiyanti, A., Khromova, S., Venderbosch, R., Yakovlev, V., Heeres, H. 2012. Catalytic hydrotreatment of fast-pyrolysis oil using non-sulfided bimetallic $\mathrm{Ni}-\mathrm{Cu}$ catalysts on a $\delta$-Al2O3 support. Applied Catalysis B: Environmental 117: 105-117.

Blakeman, P.G., Burkholder, E.M., Chen, H.-Y., Collier, J.E., Fedeyko, J.M., Jobson, H., Rajaram, R.R. 2014. The role of pore size on the thermal stability of zeolite supported Cu SCR catalysts. Catalysis Today 231: 56-63.

Bredenberg, J.-S., Huuska, M., Räty, J., Korpio, M. 1982. Hydrogenolysis and hydrocracking of the carbon-oxygen bond: I. Hydrocracking of some simple aromatic O-compounds. Journal of Catalysis 77(1): 242-247. 
Effect of Different Zeolite Supported Bifunctional Catalysts for Hydrodeoxygenation of Waste Wood Bio-oil

Bridgwater, A.V. 2012. Review of fast pyrolysis of biomass and product upgrading. Biomass and bioenergy 38: 68-94.

Bui, V.N., Laurenti, D., Afanasiev, P., Geantet, C. 2011a. Hydrodeoxygenation of guaiacol with CoMo catalysts. Part I: Promoting effect of cobalt on HDO selectivity and activity. Applied Catalysis B: Environmental 101(3-4): 239-245.

Bui, V.N., Laurenti, D., Delichère, P., Geantet, C. 2011b. Hydrodeoxygenation of guaiacol: Part II: Support effect for CoMoS catalysts on HDO activity and selectivity. Applied Catalysis B: Environmental 101(3-4): 246-255.

Centeno, A., Laurent, E., Delmon, B. 1995. Influence of the support of CoMo sulfide catalysts and of the addition of potassium and platinum on the catalytic performances for the hydrodeoxygenation of carbonyl, carboxyl, and guaiacol-type molecules. Journal of Catalysis 154(2): 288-298.

Chen, D., Rebo, H., Moljord, K., Holmen, A. 1997. Influence of coke deposition on selectivity in zeolite catalysis. Industrial \& engineering chemistry research 36(9): 3473-3479.

Chiaramonti, D., Prussi, M., Buffi, M., Rizzo, A. M., Pari, L. 2017. Review and experimental study on pyrolysis and hydrothermal liquefaction of microalgae for biofuel production. Applied Energy 185: 963-972.

Choudhary, T., Phillips, C. 2011. Renewable fuels via catalytic hydrodeoxygenation. Applied Catalysis A: General 397(1-2): 1-12.

Elliott, D.C., Hart, T.R. 2008. Catalytic hydroprocessing of chemical models for bio-oil. Energy \& Fuels 23(2): 631-637.

Ferrari, M., Bosmans, S., Maggi, R., Delmon, B., Grange, P. 2001. CoMo/carbon hydrodeoxygenation catalysts: influence of the hydrogen sulfide partial pressure and of the sulfidation temperature. Catalysis Today 65(2-4): 257-264.
Friedl, A., Padouvas, E., Rotter, H., Varmuza, K. 2005. Prediction of heating values of biomass fuel from elemental composition. Analytica Chimica Acta 544(1): 191-198.

Furimsky, E., Mikhlin, J., Jones, D., Adley, T., Baikowitz, H. 1986. On the mechanism of hydrodeoxygenation of ortho substituted phenols. The Canadian Journal of Chemical Engineering 64(6): 982-985.

González-Borja, M.Á., Resasco, D. E. 2011. Anisole and guaiacol hydrodeoxygenation over monolithic Pt-Sn catalysts. Energy \& Fuels 25(9): 4155-4162.

Hirano, T., Hirata, R., Fujinuma, Y., Saigusa, N., Yamamoto, S., Harazono, Y., Takada, M., Inukai, K., Inoue, G. 2003. $\mathrm{CO}_{2}$ and water vapor exchange of a larch forest in northern Japan. Tellus B: Chemical and Physical Meteorology 55(2): 244257.

Huber, G.W., Iborra, S., Corma, A. 2006. Synthesis of transportation fuels from biomass: chemistry, catalysts, and engineering. Chemical reviews 106 (9): 4044-4098.

Hunter, B.M., Hieringer, W., Winkler, J., Gray, H., Müller, A. 2016. Effect of interlayer anions on [NiFe]-LDH nanosheet water oxidation activity. Energy \& Environmental Science 9(5): 1734-1743.

Kim, Y.S. 2016. Current Status and Prospects on Biofuel Conversion Technologies and Facilities, Using Lignocellulosic Biomass. Journal of the Korean Wood Science and Technology 44(5): 622-628.

Lee, J.H., Moon, J.G., Choi, I.G., Choi, J.W. 2016. Study on The Thermochemical Degradation Features of Empty Fruit Bunch on The Function of Pyrolysis Temperature. Journal of the Korean Wood Science and Technology 44(3): 350-359.

Laurent, E., Delmon, B. 1994a. Influence of water in the deactivation of a sulfided NiMo $\gamma-\mathrm{Al}_{2} \mathrm{O}_{3}$ catalyst during hydrodeoxygenation. Journal of Catalysis 146(1): 281-291. 
Laurent, E., Delmon, B. 1994b. Study of the hydrodeoxygenation of carbonyl, carboxylic and guaiacyl groups over sulfided $\mathrm{CoMo} / \gamma-\mathrm{Al}_{2} \mathrm{O}_{3}$ and $\mathrm{NiMo} / \gamma$ $-\mathrm{Al}_{2} \mathrm{O}_{3}$ catalysts: I. Catalytic reaction schemes. Applied Catalysis A: General 109(1): 77-96.

Liang, N., Nakadai, T., Hirano, T., Qu, L., Koike, T., Fujinuma, Y., Inoue, G. 2004. In situ comparison of four approaches to estimating soil $\mathrm{CO}_{2}$ efflux in a northern larch (Larix kaempferi Sarg.) forest. Agricultural and Forest Meteorology 123(1-2): 97-117.

Lippens, B.C., De Boer, J. 1965. Studies on pore systems in catalysts: V. The t method. Journal of Catalysis 4(3): 319-323.

Long, J., Xu, Y., Wang, T., Yuan, Z., Shu, R., Zhang, Q., Ma, L. 2015. Efficient base-catalyzed decomposition and in situ hydrogenolysis process for lignin depolymerization and char elimination. Applied Energy 141: 70-79.

Lu, Q., Li, W.-Z., Zhu, X.-F. 2009. Overview of fuel properties of biomass fast pyrolysis oils. Energy Conversion and Management 50(5): 1376-1383.

Moon, J.G., Hwang, H., Lee, J.H., Choi, I.G., Choi, J.W. 2016. Effect of Inorganic Constituents Existing in Empty Fruit Bunch (EFB) on Features of Pyrolysis Products. Journal of the Korean Wood Science and Technology 44(5): 629-638

Mortensen, P.M., Grunwaldt, J.-D., Jensen, P.A., Knudsen, K., Jensen, A.D. 2011. A review of catalytic upgrading of bio-oil to engine fuels. Applied Catalysis A: General 407(1-2): 1-19.

Munnik, P., de Jongh, P.E., de Jong, K.P. 2015. Recent developments in the synthesis of supported catalysts. Chemical reviews 115(14): 6687-6718.

Nimmanwudipong, T., Runnebaum, R.C., Block, D.E., Gates, B.C. 2011a. Catalytic conversion of guaiacol catalyzed by platinum supported on alumina: Reaction network including hydrodeoxygenation reactions. Energy \& Fuels 25(8): 3417-3427.
Nimmanwudipong, T., Runnebaum, R.C., Block, D.E., Gates, B.C. 2011b. Catalytic reactions of guaiacol: reaction network and evidence of oxygen removal in reactions with hydrogen. Catalysis letters 141(6): 779-783.

Nimmanwudipong, T., Runnebaum, R.C., Ebeler, S.E., Block, D.E., Gates, B.C. 2012. Upgrading of ligninderived compounds: reactions of eugenol catalyzed by $\mathrm{HY}$ zeolite and by $\mathrm{Pt} / \gamma-\mathrm{Al}_{2} \mathrm{O}_{3}$. Catalysis letters 142(2): 151-160.

Ochoa-Hernández, C., Yang, Y., Pizarro, P., Víctor, A., Coronado, J.M., Serrano, D.P. 2013. Hydrocarbons production through hydrotreating of methyl esters over Ni and Co supported on SBA-15 and Al-SBA-15. Catalysis today 210: 81-88.

Oh, S., Choi, H.S., Choi, I.-G., Choi, J.W. 2017. Evaluation of hydrodeoxygenation reactivity of pyrolysis bio-oil with various Ni-based catalysts for improvement of fuel properties. RSC Advances 7(25): 15116-15126.

Ohta, H., Yamamoto, K., Hayashi, M., Hamasaka, G., Uozumi, Y., Watanabe, Y. 2015. Low temperature hydrodeoxygenation of phenols under ambient hydrogen pressure to form cyclohexanes catalysed by Pt nanoparticles supported on H-ZSM-5. Chemical Communications 51(95): 17000-17003.

Olcese, R., Bettahar, M., Petitjean, D., Malaman, B., Giovanella, F., Dufour, A. 2012. Gas-phase hydrodeoxygenation of guaiacol over $\mathrm{Fe} / \mathrm{SiO}_{2}$ catalyst. Applied Catalysis B: Environmental 115: 63-73. Prajitno, H., Insyani, R., Park, J., Ryu, C., Kim, J. 2016. Non-catalytic upgrading of fast pyrolysis bio-oil in supercritical ethanol and combustion behavior of the upgraded oil. Applied Energy 172: 12-22. Shemfe, M., Gu, S., Fidalgo, B. 2017. Techno-economic analysis of biofuel production via bio-oil zeolite upgrading: An evaluation of two catalyst regeneration systems. Biomass and Bioenergy 98: 182-193. 
Effect of Different Zeolite Supported Bifunctional Catalysts for Hydrodeoxygenation of Waste Wood Bio-oil

Wen, J.-L., Sun, S.-L., Yuan, T.-Q., Xu, F., Sun, R.-C. 2014. Understanding the chemical and structural transformations of lignin macromolecule during torrefaction. Applied Energy 121: 1-9.

Wildschut, J., Mahfud, F.H., Venderbosch, R.H., Heeres, H.J. 2009. Hydrotreatment of fast pyrolysis oil using heterogeneous noble-metal catalysts. Industrial \& Engineering Chemistry Research 48(23): 10324-10334.

Yakovlev, V., Khromova, S., Sherstyuk, O., Dundich, V., Ermakov, D.Y., Novopashina, V., Lebedev, M. Y., Bulavchenko, O., Parmon, V. 2009. Development of new catalytic systems for upgraded biofuels production from bio-crude-oil and biodiesel. Catalysis Today 144(3-4): 362-366.

Yao, G., Wu, G., Dai, W., Guan, N., Li, L. 2015. Hydrodeoxygenation of lignin-derived phenolic compounds over bi-functional Ru/H-Beta under mild conditions. Fuel 150: 175-183.

Zakzeski, J., Bruijnincx, P.C., Jongerius, A.L., Weckhuysen, B.M. 2010. The catalytic valorization of lignin for the production of renewable chemicals. Chemical reviews 110(6): 3552-3599.

Zhang, W., Yu, D., Ji, X., Huang, H. 2012. Efficient dehydration of bio-based 2, 3-butanediol to butanone over boric acid modified HZSM-5 zeolites.
Green chemistry 14(12): 3441-3450.

Zhang, X., Tang, W., Zhang, Q., Wang, T., Ma, L. 2018. Hydrodeoxygenation of lignin-derived phenoic compounds to hydrocarbon fuel over supported Ni-based catalysts. Applied Energy 227: 73-79.

Zhang, X., Zhang, Q., Wang, T., Ma, L., Yu, Y., Chen, L. 2013. Hydrodeoxygenation of lignin-derived phenolic compounds to hydrocarbons over $\mathrm{Ni} / \mathrm{SiO}_{2}{ }^{-}$ $\mathrm{ZrO}_{2}$ catalysts. Bioresource technology 134: 73-80.

Zhang, Y., Bi, P., Wang, J., Jiang, P., Wu, X., Xue, H., Liu, J., Zhou, X., Li, Q. 2015. Production of jet and diesel biofuels from renewable lignocellulosic biomass. Applied Energy 150: 128-137.

Zhao, C., Lercher, J.A. 2012. Upgrading pyrolysis oil over Ni/HZSM- 5 by cascade reactions. Angewandte Chemie 124(24): 6037-6042.

Zhao, H., Li, D., Bui, P., Oyama, S. 2011. Hydrodeoxygenation of guaiacol as model compound for pyrolysis oil on transition metal phosphide hydroprocessing catalysts. Applied Catalysis A: General 391(1-2): 305-310.

Zhu, X., Lobban, L.L., Mallinson, R.G., Resasco, D.E. 2011. Bifunctional transalkylation and hydrodeoxygenation of anisole over a Pt/HBeta catalyst. Journal of Catalysis 281(1): 21-29. 